\title{
THE INFLUENCE OF TAX RATE AND INCOME LEVEL ON TAX NON-COMPLIANCE IN TANZANIA
}

\author{
CHRISTINA KIHANGA \\ Mzumbe Mbeya Campus College, \\ P.O. Box 6559 Mbeya, Tanzania \\ https://doi.org/10.37602/IJSSMR.2020.3410
}

\begin{abstract}
Tax compliance is a major problem for many tax authorities around the world and Governments continuously attempt to improve the level of tax compliance especially those in countries which face a high level of tax non- compliance. Tanzania is one of these countries in which tax non-compliance has been reported to be at a high level during the last few decades. This paper empirically investigates the influence of tax rate and income level on individual taxpayer's non- compliance behaviour in Tanzania. This study is underpinned by the social influence theory and further supported by the deterrence theory and cognitive learning theory. Data were collected through survey questionnaires and analysed using multiple regression analysis and other statistical techniques. Distributed questionnaires totalled 491 that yielded 384 usable questionnaires. The results reveal that there is a positive significant relationship between tax rate and tax non-compliance, whereas the relationship between income level and tax non-compliance is negatively significant. This study concludes with the theoretical implications and practical recommendations for the Tanzania Government in order to improve tax collection such as to develop and implement more stringent enforcement strategies to improve the tax system in terms of penalty rate and tax rates. In addition, the Tanzania Tax Authority should play a more proactive role to encourage and educate individual taxpayers by enhancing their knowledge of taxation.
\end{abstract}

Keywords: tax rate, income level, non-compliance, Tanzania

\subsection{INTRODUCTION}

Taxpayers willingness to comply with the tax laws could be influenced by various factors including their perception of the government. Taxpayers should be fully satisfied with the government; only then will it result in a positive perception of and behaviour towards paying tax. The social influence theory points out that individuals are usually affected by their surroundings (Snavely, 1990). Thus, in order to reduce the non-compliance level, taxpayers should have a positive perception of the government, which in turn, will influence their behaviour. In other words, a clear and transparent government is considered as an important factor that could positively influence the behaviour of taxpayers. On the other hand, a corrupt government may lead to a high level of rejection of the laws among the people and may lead to tax non-compliance. 


\section{International Journal of Social Sciences and Management Review}

Most taxpayers in developing countries consider two criteria: the tax rate and penalty rate, if they intend to evade tax (Umar, Kasim \& Martin, 2012). Further, Charles (2019) argued that taxpayers use the high tax rate as an opportunity to not only evade taxes but also to underreport their earnings when filing their taxes. Kamasa, Adu, \& Oteng-Abayie (2019) found that a higher tax rate discourages tax compliance. However, Doran (2009) explained that tax penalties always motivate taxpayers to comply with tax laws. Additionally, previous studies on tax non- compliance have reported that the low level of income influences tax noncompliance in Tanzania (Charles, 2019; Fjeldstad, 2019; Night \& Bananuka, 2019) established that the level of education has a strong impact on reducing the level of tax noncompliance. Therefore, all these factors are relevant to be examined in the context of Tanzanian's individual taxpayers.

\subsection{LITERATURE REVIEW}

Tax is considered as a crucial instrument and primary source of revenue for most governments since tax revenue or income is needed to finance critical programmes (e.g., health care, education); services (e.g., law enforcement, public utilities); and infrastructure (e.g., road construction, environmental protection), which are beneficial to the society) Worlu \& Nkoro, 2012). Unfortunately, the non-compliance problem prevents the government from generating sufficient revenue, thus adversely affecting the financing of the activities. Therefore, the tax non-compliance issue has attracted the attention of researchers in the area, such as Kirchler (2007); and Khan and Ahmad (2014). The problem of tax noncompliance is considered an important and significant phenomenon that affects both developed and developing economies (Hindriks, Peralta \& Weber, 2008).

Tax compliance has evolved into a major research topic in economic psychology. The issue has been approached from various viewpoints shedding light on different aspects of taxpayers' behaviour. Internationally, the issue of tax non-compliance has been examined in different countries, such as the United States, Malaysia, New Zealand, Australia, Tanzania and Sweden, which have focused on the legal and economic perspectives. Various studies have been carried out to investigate this issue, such as McGee, Petrides and Ross (2012); and Saad (2012). However, the related literature has reported that most studies conducted on tax non-compliance have focused on the classic model of tax compliance, which is based on the economic perspective of the deterrence theory. The lack of empirical research on other aspects can be attributed to the reality that social effects are extremely difficult to identify (Gupta \& McGee, 2010). McGee and Lingle (2006) investigated tax non-compliance in selected countries from the developed world, including in North America, South America and Europe and Australia and New Zealand. They found that due to their level of education and awareness as well as the stringent and appropriate measures put in place by tax authorities, the non-compliance attitude was less or minimal compared to developing countries. Furthermore, Yusof, Ling and Wah (2014) examined tax non-compliance in the context of Malaysia the study found that peripheral tax rate, firm size and types of industry exerted significant effects on tax non-compliance.

Normally, a positive perception of tax payment leads to a reduction in tax non- compliance (Al-Jaaidi, Manaf \& Karlinsky, 2011). The social influence theory stipulates that a person is affected by the environment that surrounds him or her. In other words, an individual's 


\section{International Journal of Social Sciences and Management Review}

behaviour is intentionally or unintentionally influenced by others in the surrounding area. Many studies have been done on the perception of taxpayers towards tax non-compliance, but most studies on tax non-compliance have looked at the issue from a public finance or economic perspective, such as studies that applied the Fischer model (Palil \& Mustapha, 2011). It has been found that compliance with tax regulations is not always fully achieved even in developed nations (McGee, López Paláu \& Polanco, 2007). Thus, it is crucial to investigate the perception of Tanzania taxpayers as they act according to their own perception, be it positive or negative. Furthermore, the paper investigates the influence of tax rate, income level and education level on tax non-compliance in Tanzania.

\subsection{Tax Rate}

Tax rate plays a significant role in influencing investment and financing decisions of organisations. A tax rate which is below marginal personal income tax rates can provide incentives for the self-employed to incorporate their business (King, 1977). Tax rate refers to the quantum of tax that a taxpayer has to pay in accordance with the taxable items and tax law. Several studies in both developed and developing countries have been undertaken on the relationship between tax rate and tax non- compliance behaviour, whereby their findings show there is a positive relationship (Muhrtala \& Ogundeji, 2013; Gurama 2015). Overall, these studies have shown that the tax rate is directly related to the taxpayers' ability to behave positively or negatively based on their perception of tax non-compliance. Taxpayers use the high tax rate as an excuse to evade taxes and/or under-report their income to the tax authorities. James and Moses (2012) posited that there is a positive relationship between tax rate and tax non-compliance. Maria and Judith (2013) found that a higher tax rate can discourage tax compliance. Adebisi and Gbegi (2013); and Gurama (2015) pointed out that there is a positive and significant relationship between tax rate and tax non-compliance in Nigeria. These studies are in line with previous studies which have shown that there is a positive relationship between tax rate and tax non-compliance. The studies conclude that high tax rate attracts non-compliance and encourages tax non- compliance. Yusof et al. (2014), in their study on tax non-compliance in Malaysia, found that there is a direct relationship between tax rate and tax non-compliance. Also, Teng and Manual (2016), in their study on economic factors influencing taxpayers' non- compliance behaviour in Malaysia, found the same relationship. However; Olowookare and Fasina (2013); and Adebisi and Gbegi (2013), did not find a positive relationship between tax rate and tax non-compliance. Ibadin and Eiya (2013) studied the behaviour of self-employed Nigerians and tax non-compliance. They found that there is no relationship, either negative or positive, between tax non- compliance and tax rate.

The studies in Tanzania, in particular, are extremely limited with only a few studies which have offered possible explanations for the influence of tax rate (Al-Ttaffi \& Abdul-Jabbar, 2016). Al-Ttaffi, (2009) examined the influence of tax rate on tax evasion and found a positive relationship between tax rate and tax evasion. Al-Jaaidi et al. (2011) conducted a study to find out the perception of Yemenis towards tax evasion. The study was concerned with whether or not tax evasion is considered to be a crime and found a positive relationship. Based on the above discussion on the relationship between tax rate and tax non- compliance, it is found that there is inconsistency in all the studies reviewed. In addition, studies on tax 


\section{International Journal of Social Sciences and Management Review}

rate have received scant attention in Tanzania. Therefore, this study investigates the effect of tax rate on tax non-compliance.

\subsection{Income Level}

Taxpayers must pay taxes to finance public services. Various modes are utilised to decide how much tax a person must pay according to his or her earnings. There is evidence in the literature that low-salary workers are very prone to tax avoidance (John \& Slemrod, 2008). In their study, they showed that several cases of underreported taxes are by low-income earners. Alm et al. (1992) posited that high- income earners do not evade taxes as much as low-salary workers. In other words, high income is positively related to increased compliance. Alm et al. (1992) reported that higher income leads to higher reported income. They found that there is a positive relationship between the income level of taxpayers and tax non-compliance. Furthermore, Seren and Panades (2007) reported a positive relationship between income level and tax non-compliance. As the income level increase, there should be a corresponding increase in the tax rate. This may, in turn, encourage taxpayers to avoid the high tax bracket by hiding some of their income to shift to a lower income bracket. Other studies have shown the existence of a relationship between income level and tax non-compliance, including the work of Nor Ghani et al. (2012) in Malaysia; Malkawi and Haloush (2008) in Jordan; and Devos (2006) in Australia \& New Zealand. They found that income level and tax noncompliance have a significant relationship. Many factors are responsible for tax compliance, including the way a taxpayer thinks when reporting and complying with the tax authorities, and not just his or her income level. Also, Engida and Baisa (2014) found that the relationship between income level and tax non-compliance is positive and significant. It shows that the income of the taxpayer decides the level of his or her compliance.

On the other hand, Baldry (1987), in his study, found that income level and tax noncompliance does not have a significant relationship, implying that there is no impact of high or low income on the decision of a taxpayer to evade taxes. This is in tandem with the findings of Christian (1994); and Fishlow \& Friedman (1994) while others have reported a negative relationship (Collins \& Plumlee, 1991; Slemrod, 1985) or no relationship (Feinstein, 1991; Kirchler et al., 2010). Furthermore, Jackson and Milliron (1986) found that income level has a mixed and unclear impact on compliance, and some later research has agreed with that statement. Moreover, in the Tanzania context, only a few studies have examined the relationship between income level and tax non-compliance. For example, Helhel and Ahmed (2014) examined the influence of income level on tax evasion and found a positive relationship between income level and tax evasion, while Al-Ttaffi (2009) found a negative relationship. Based on the above discussion on the relationship between income level and tax non- compliance, it is found that there is inconsistency in all the literature reviewed. Also, the study on income level has received scant attention in Yemen. Therefore, this study also, investigates the influence of income level on tax non-compliance of taxpayers in Tanzania.

\subsection{RESEARCH METHODS}

The objectives of the present research are to determine the factors influencing tax noncompliance in Tanzania. In order to achieve the objectives of the study, the study used a survey method to collect data. A survey is a way to attain self-reporting information about the 


\section{International Journal of Social Sciences and Management Review}

assertiveness, ideas, opinions and behaviour and other characteristics of the population (Jain \& Srivastava, 2013). This study used a quantitative research approach. It is a cross-sectional study in which the data was collected and analysed at a point of time only. Furthermore, a questionnaire was used for data collection to help understand the relationship between the independent and dependent variables based on the responses from the target respondents. This approach is supported by Sekaran (2003), who stated that questionnaires are an efficient method for collecting data. A questionnaire is set to cover all the important constructs of the proposed research framework. The data for this study was analysed using the Statistical Package for Social Sciences (SPSS) version 23.

\subsection{RESULT}

Factor analysis is one of the statistical methods to determine the variability among particular factors, and also to minimise a large number of related factors to a more manageable number (Pallant, 2007). By using principal axis factor analysis with varimax rotation, the analysis was conducted to extract all the four constructs, i.e. the perception of corruption in the government, tax rate, penalty rate and tax non- compliance. The identification data matrix was executed to check the data in this paper through Kaiser-Meyer-Olkin (KMO) value besides Bartlett's Test of Sphericity. KMO measure of sampling adequacy value was 0.807 , exceeding the recommended value of 0.50 (Hair et al., 2010), while Bartlett's test of sphericity was 2847.010 , which was also found to be significant $(\mathrm{p}=.000)$.

As presented in Table 1 the data matrix examination indicates that the factor analysis application on the three variables is fit since the KMO, the tax rate is 0.807 and tax noncompliance is 0.631 , with variance explained ranging between $69.9 \%$ and $70.8 \%$. The value of KMO which is above 0.50 is acceptable. Therefore, the KMO measure of sampling adequacy is acceptable for this study because it is greater than 0.50 (Hair et al., 2010). In addition, factor analysis test shows that all factor loadings are between 0.610 and 0.807 , which is an acceptable range (Hair et al., 2010).

Table 1: Factor Analysis $(n=384)$

\begin{tabular}{|c|c|c|c|c|c|}
\hline Variable & & $\begin{array}{l}\text { No } \\
\text { of } \\
\text { Item } \\
\text { s } \\
\end{array}$ & $\begin{array}{l}\text { No of } \\
\text { Factor } \\
\text { S }\end{array}$ & KMO & $\begin{array}{l}\text { Variance } \\
\text { Explained } \\
(\%)\end{array}$ \\
\hline Tax rate & 5 & & 1 & 0.807 & 69.90 \\
\hline Income Level & 4 & & 1 & 0.757 & 67.63 \\
\hline Tax non-compliance & 3 & & 1 & 0.631 & 70.83 \\
\hline
\end{tabular}

\section{Pearson Correlation Analysis}

Pearson Correlation matrix shows the direction, significance and strength of the bivariate associations between the variables of the study. Table 2 shows the relationship between tax non-compliance (dependent variable) and the two variables, i.e., tax rate and income level (independent variables) 


\section{International Journal of Social Sciences and Management Review}

Table 2: Pearson Correlations Matrix

\begin{tabular}{lccc}
\hline Variables & $\begin{array}{c}\text { Tax non- } \\
\text { compliance }\end{array}$ & $\begin{array}{c}\text { Tax } \\
\text { rate }\end{array}$ & $\begin{array}{c}\text { Income } \\
\text { level }\end{array}$ \\
$\begin{array}{l}\text { Tax non- } \\
\text { complianc }\end{array}$ & & & \\
$\mathrm{e}$ & & & \\
Tax rate & $.425 * *$ & 1 & \\
Income level & $.280 * *$ & $.816 * *$ & 1
\end{tabular}

Note: ** Correlation is significant at the 0.01 level (2-tailed)

The result of the correlation conducted on the two independent variables shows they are significant and positively correlated and have a positive direction with tax non- compliance. Table 2 shows that tax rate and income level, are correlated positively with tax noncompliance at 0.425 and 0.280 , respectively and significant at the 0.01 level. Overall, the result of the correlation analysis suggests that there is a fair degree of linear relationships among the variables.

\section{Multiple Regressions}

Multiple regressions is a procedure that includes one dependent variable with two or more independent variables. In other words, the test is used to assess the simultaneous impact of many independent variables on a dependent variable. This procedure helps researchers to understand how much of the variance in the dependent variable is explained by a set of independent variables (Cavana, Delahaye \& Sekaran, 2001). In this section, by deploying multiple regressions technique, the analysis is more focused on the relationship between the dependent variable, i.e., tax non-compliance and independent variables, i.e., tax rate, income level. Multiple regressions analysis is the most common method used in a situation whereby the research is intended to predict a continuous independent variable toward a single continuous dependent variable (Genser, Strina, Teles, Prado, \& Barreto, 2007). The result of multiple regressions analysis of this paper is shown in Table 3

Table 3: Summary of the Regression Model $(n=384)$

\begin{tabular}{lllcc}
\hline Model & R & $\begin{array}{l}\text { R } \\
\text { Square }\end{array}$ & $\begin{array}{l}\text { Adjusted } \\
\text { R } \\
\text { Square }\end{array}$ & $\begin{array}{l}\text { Std. Error } \\
\text { of } \\
\text { Estimate }\end{array}$ \\
\hline 1 & $\begin{array}{l}0.668 \\
\mathrm{a}\end{array}$ & 0.446 & 0.435 & 0.70093 \\
\hline
\end{tabular}

a. Predictors: (Constant), Tax Rate and Income Level

b. Dependent variable: Tax Non-compliance

The regression result as presented in Table 4 shows that adjusted $\mathrm{R} 2=0.435$, which indicates that the predictor variables, i.e., tax rate and income level explain $43.5 \%$ of the variance in tax non-compliance. The result of ANOVA analysis as shown in Table 4, presents that F 


\section{International Journal of Social Sciences and Management Review}

value of 41.507 is significant at the 0.000 level of significance. Therefore, it can be concluded that the model in this paper is appropriate and fit. Moreover, the general regression model with two predictor variables has run well in defining tax non-compliance.

Table 4: ANOVA

\begin{tabular}{|c|c|c|c|c|c|}
\hline Model & $\begin{array}{l}\text { Sum of } \\
\text { Square } \\
\text { S }\end{array}$ & df & $\begin{array}{l}\text { Mean } \\
\text { Squar } \\
\text { e }\end{array}$ & $\mathbf{F}$ & Sig. \\
\hline Regression & 101.963 & 5 & $\begin{array}{l}20.39 \\
3\end{array}$ & $\begin{array}{l}41.50 \\
7\end{array}$ & $\begin{array}{l}0.000 \\
\text { b }\end{array}$ \\
\hline Residual & 126.758 & 258 & 0.491 & & \\
\hline Total & 228.721 & 263 & & & \\
\hline
\end{tabular}

a. Predictors: (Constant), Tax Rate, and Income Level

b. Dependent variable: Tax Non-compliance

According to Lind, Marchal and Wathen (2013); and Kumar, Talib and Ramayah (2013), the t-value $>1.9645$ shows that the relationships between the independent and dependent variables are significant, and thus the hypotheses are accepted.

Table 5

Multiple Regressions Analysis

\begin{tabular}{llllll}
\hline Model & \multicolumn{2}{l}{$\begin{array}{l}\text { Unstandardize } \\
\text { d Coefficients }\end{array}$} & $\begin{array}{l}\text { Standardize } \\
\text { d } \\
\text { Coefficients }\end{array}$ \\
\cline { 2 - 6 } & $\boldsymbol{\beta}$ & Std. Error & Beta & t & Sig. \\
\hline $1 \quad$ (Constant) & 0.252 & 0.302 & & 0.833 & 0.406 \\
Tax rate & 0.328 & 0.101 & 0.279 & 3.245 & $0.001 * * *$ \\
Income level & 0.354 & 0.175 & 0.266 & 2.056 & $0.041^{* * *}$ \\
\hline
\end{tabular}

As depicted in Table 5, the t-values of four independent variables, i.e. tax rate, and income level are more than 1.9645; therefore, these variables have a significant relationship with the dependent variable, i.e., tax non-compliance.

\subsection{DISCUSSION}

This paper has provided empirical evidence about the factors that determine taxpayers' noncompliance behaviour in Tanzania. This study investigates the determinants of tax noncompliance from economic and social perspectives in Tanzania. The results reveal that tax rate positively affects tax non-compliance. Also, it reveals that income level negatively affects tax non- compliance. Therefore, the Tanzania government and tax authority should 


\section{International Journal of Social Sciences and Management Review}

take note of the factors that influence taxpayers' behaviour, which could be useful to reduce the problems.

\section{REFERENCE}

Adebisi, J. F., \& Gbegi, D. O. (2013). Effect of tax avoidance and tax evasion on personal income tax administration in Nigeria. American Journal of Humanities and Social Sciences, 1(3), 125-134.

Al-Jaaidi, K. S., Manaf, N. A. A., \& Karlinsky, S. S. (2011). Tax evasion as a crime: A survey of perception in Yemen. International Journal of Business and Management, 6(9), 190-201

Alm, J., Jackson, B. R., \& McKee, M. (1992). Estimating the determinants of taxpayer compliance with experimental data. National Tax Journal 45(1), 107-114.

Al-Ttaffi, L., (2009). Determinants of tax evasion: An empirical evidence from the Republic of Yemen. (Unpublished Master Dissertation, Universiti Utara Malaysia).

Al-Ttaffi, L., \& Abdul-Jabbar, H. (2016). Geopolitics and its implications for tax administration. International Conference on Government \& Public Affair (ICOGPA), Sintok, Malaysia, 05 - 06 October. School of Government, Universiti Utara Malaysia.

Baldry, J. C. (1987). Income tax evasion and the tax schedule: Some experimental results. Public Finance $=$ Finances publiques, 42(3), 357-83.

Cavana, R. Y., Delahaye, B. L., \& Sekaran, U. (2001). Applied business research: Qualitative and quantitative methods. Milton: John Wiley \& Sons Australia Ltd

Charles, G. (2019). Coordinating regulatory agencies for improved tourism policy in Tanzania. Journal of Hospitality and Tourism Insights, 2(1), 2-17. https://doi.org/10.1108/JHTI-08-2018-0049

Christian, C. W. (1994). Voluntary compliance with the individual income tax: results from the 1988 TCMP study. The IRS Research Bulletin, 1500, 35-42.

Collins, J. H., \& Plumlee, R. D. (1991). The taxpayer's labor and reporting decision: The effect of audit schemes. Accounting Review, 559-576.

Devos K. (2006). The Attitude of Australian and New Zealand Tertiary Student Towards Tax Evasion: A Comparative Study and Demographic Analysis. New Zealand Journal of Taxation Law and Policy, 12 (4), 293-323

Doran, M. (2009) Tax Penalties and Tax Compliance: A Personal Income Tax NonCompliance in Malaysia. PhD Thesis, Victoria University, Melbourne. Harvard Journal on Legislation, 46(1). 


\section{International Journal of Social Sciences and Management Review}

Engida, T. G., \& Baisa, G. A. (2014). Factors Influencing taxpayers' compliance with the tax system: An empirical study in Mekelle City, Ethiopia. eJournal of Tax Research, $12(2), 433$.

Feinstein, J. S. (1991). An econometric analysis of income tax evasion and its detection. The RAND Journal of Economics, 14-35.

Fjeldstad, P. O. (2019). Electronic Fiscal Devices (EFDs ): Lessons from the Region and Mainland Tanzania Structure of the presentation

Fishlow, A., \& Friedman, J. (1994). Tax evasion, inflation and stabilization.

Journal of Development Economics, 43(1), 105-123.

Genser B, Strina A, Teles CA, Prado MS, Barreto ML(2007). Risk Factors for Childhood Diarrhea Incidence; Dynamic Analysis of A Longitudinal Study. Epidemiology. ;17(6):658-667.

Gupta. R \& McGee. R (2009) An Empirical Study of Demographics of Perception of Tax Evasion in New Zealand. New Zealand Journal of Taxation Law and Policy 65.

Gurama, Z. (2015) Tax Evasion Determinants: Evidence From Nigeria.(Unpublished Master Dissertation), Universiti Utara Malaysia.

Hair, J. F., Black, W. C., Babin, B. J., \& Anderson, R. E. (2010). Multivariate data analysis: A global perspective. New Jersey: Pearson Education, Inc.

Helhel, Y., \& Ahmed, Y. (2014). Factors affecting tax attitudes and tax compliance: a survey study in Yemen. European Journal of Business and Management, 6(22), 48-58.

Hindriks, J., Peralta, S., \& Weber, S. (2008). Competing in taxes and investment under fiscal equalization. Journal of public economics, 92(12), 2392-2402.

Ibadin, P. O., \& Eiya, O. F. I. A. F. O. H. (2013). Tax evasion and avoidance behaviour of the self-employed Nigerians. European Journal of Business and Management, 5(6), 1-16.

Jackson, B. R.,\&Milliron,V. C. (1986).Tax compliance research: Findings, problems and prospects. Journal of Accounting Literature, 5, 125-165.

Jain, N., \& Srivastava, V. (2013). Data mining techniques: a survey paper. IJRET: International Journal of Research in Engineering and Technology, 2(11), 2319-1163.

Johns, A., \& Slemrod, J. (2008).The distribution of income tax non-compliance.

Retrived From http://www.bus.umich.edu/otpr/DITN\%20091308.pdf

Kamasa, K., Adu, G., \& Oteng-Abayie, E. F. (2019). Tax Compliance in Sub-Saharan Africa: How Important are Non-Pecuniary Factors? African Journal, VII(I). 


\section{International Journal of Social Sciences and Management Review}

Volume: 03, Issue: 04 "July - August 2020"

ISSN 2582-0176

Khan, W. A., \& Ahmad, P. F. (2014). Causes of Tax Evasion in Pakistan: A case study on southern Punjab. International Journal of Accounting and Financial Reporting, 4(2), 273-294

Kirchler, E. (2007). The economic psychology of tax behaviour. Cambridge: Cambridge University Press.

Kirchler, E., Muehlbacher, S., Kastlunger, B., \& Wahl, I. (2010). Why pay taxes? A review of tax compliance decisions. Developing alternative frameworks for explaining tax compliance, 15-31.

Kumar, M., Talib, S. A., \& Ramayah, T. (2013). Business Research Methods.

Oxford Fajar/Oxford University Press.

Lind, D. A., Marchal, W. G., \&Wathen, S. A. (2013). Basic Statistics for Business and Economic (8th ed.). McGraw-Hill Education (Asia).

Malkawi, B. H., \& Haloush, H. A. (2008). The case of income tax evasion in Jordan: symptoms and solutions. Journal of Financial Crime, 15(3), 282- 294.

McGee, R and Bose, S. (2007). The Ethics of Tax Evasion: A Comparative Study of Australian, New Zealand \& the U.S.A opinions. Andreas School of Business. Working Paper.

McGee, R. W., \& Lingle, C. (2006). Tax Evasion and Business Ethics: A Comparative Study of Guatemala and the USA. Available at SSRN 892323.

McGee, R. W., Petrides, Y., \& Ross, A. M. (2012). How Serious Is Tax Evasion? A Survey of Mexican Opinion. In The Ethics of Tax Evasion 405-411. Springer New York.

Muhrtala, T. O., \& Ogundeji, M. (2013). Professionals' Perspective of Tax Evasion: Some Evidence from Nigeria. Universal Journal of Accounting and Finance, 1(2), 35-41.

Night, S., \& Bananuka, J. (2019). The mediating role of adoption of an electronic tax system in the relationship between attitude towards electronic tax system and tax compliance. Journal of Economics, Finance and Administrative Science, JEFAS-07-2018-0066. https://doi.org/10.1108/JEFAS-07-2018-0066

Nor Ghani Md. Nor, Mansor J., Mohd A. S. Z., and Razieh T. (2012) Estimating Factors Affecting Tax Evasion in Malaysia: A Neural Network Method Analysis. Prosiding PERKEM VII, JILID 2. 1524 - 1535.

Olowookere, J. K., \& Fasina, H. T. (2013). Taxpayers' Education: A Key Strategy in Achieving Voluntary Compliance in Lagos State, Nigeria. European Journal of Business and Management, 5(10), 146-154. 


\section{International Journal of Social Sciences and Management Review}

Volume: 03, Issue: 04 "July - August 2020"

ISSN 2582-0176

Palil, M. R., \& Mustapha, A. F. (2011). Factors affecting tax compliance behaviour in selfassessment system. African journal of business management, 5(33), 12864.

Pallant, J. (2007). SPSS survival manual: A step by step guide to data analysis using SPSS for windows -version 15 (3rd ed.). Crow’s Nest: Open University Press.

Saad, N. (2012). Tax Non-Compliance Behaviour: Taxpayers View. Procedia- Social and Behavioral Sciences, 65(1), 344-351.

Sekaran, U. (2003). Research Methods more Business: A Skill-Building Approach (3rd ed.). New York: John Wiley \& Son.

Seren, M. and Panades, J. (2007). Does tax evasion modify the redistributive effect of tax progressivity?.The School of Economics at the Australian National University, Australia.Working Paper Number 102.

Slemrod, J. (1985). An empirical test for tax evasion.Review of Economics and Statistics, 67(2), 232-238.

Snavely, K. 1990. Governmental policies to reduce tax evasion: coerced behaviour versus services and values development. Policy Sciences, 23, 57-72.

Teng, Y. M., \& Manual, V. (2016). A Study about Economic Factors Influencing Taxpayers' Noncompliance Behaviors in Kuala Lumpur, Malaysia. Imperial Journal of Interdisciplinary Research, 2(9).

Umar, M. A., Kasim, R., \& Martin, D. J. (2012). An overview of property tax collection as a tool for a sustainable local government reform in Malaysia. International Conference on Technology Management, Business and Entrepreneurship 2012 (ICTMBE 2012), 18-19 December 2012

Worlu, C. N., \& Nkoro, E. (2012). Tax revenue and economic development in Nigeria: A macroeconometric approach. Academic Journal of Interdisciplinary Studies, 1(2), 211-223. 